\title{
Effect of nitrogen, phosphate and potassium fertilization on dystrophic soil on the content of secondary metabolites in Hydrocotyle umbellata L. var. bonariensis (Lam.)
}

\section{Spreng}

\author{
Efeito da fertilização com nitrogênio, fosfato e potássio em solo distrófico sobre o conteúdlo de \\ metabólitos secundários em Hydrocotyle umbellata L. var. bonariensis (Lam.) Spreng
}

Efecto de la fertilización con nitrógeno, fosfato y potasio en suelo distrófico sobre el contenido de metabolitos secundarios en Hydrocotyle umbellata L. var. bonariensis (Lam.) Spreng

André Luiz Ribas de Oliveira

ORCID: https://orcid.org/0000-0002-7131-6518 Universidade Estadual de Goiás, Brasil E-mail: andre_luiz_ueg@yahoo.com.br Matheus Gabriel de Oliveira ORCID: https://orcid.org/0000-0003-0692-9729 Universidade Federal de Goiás, Brasil E-mail: matheusgabrie106@hotmail.com

José Realino de Paula

ORCID: https://orcid.org/0000-0002-4424-7692 Universidade Federal de Goiás, Brasil E-mail: jose realino@ufg.b João Carlos Mohn Nogueira

ORCID: https://orcid.org/0000-0001-5597-7386 Universidade Estadual de Goiás, Brasi E-mail: jcmnogueira1@hotmail.com Vandervilson Alves Carneiro

ORCID: https://orcid.org/0000-0002-7286-0806 Universidade Estadual de Goiás, Brasil E-mail: vandervilson.carneiro@ueg.br

Lídia Vitoriano de Sousa

ORCID: https://orcid.org/0000-0001-6990-0013 Universidade Federal de Goiás, Brasil E-mail: lvitorianodesousa@gmail.com Andressa Tuane Santana Paz

ORCID: https://orcid.org/0000-0002-2754-7474 Universidade Federal de Goiás, Brasil E-mail: andressa.santanapaz@gmail.com

Edemilson Cardoso da Conceição ORCID: https://orcid.org/0000-0003-4113-2686 Universidade Federal de Goiás, Brasil E-mail: edemilson_conceicao@ufg.br

Camila Aline Romano

ORCID: https://orcid.org/0000-0002-3564-6368 Universidade Federal de Goiás, Brasil E-mail: camilaalineromano@gmail.com

Karen Beatriz Ferreira Morais

ORCID: https://orcid.org/0000-0002-8160-9728 Universidade Federal de Goiás, Brasil E-mail: karenferreira.ar@gmail.com

\begin{abstract}
The knowledge of medicinal plants is of great importance for popular health. On the other hand, the levels of secondary metabolites in medicinal plants is an important parameter to be evaluated. The study of the nutrition of plants and the production of metabolites can provide the identification of beneficial factors and also find out if there are harmful effects of this fertilization/nutrition. In this study, three experiments were carried out (nitrogen, phosphate and potassium fertilization) in the culture of Hydrocotyle umbellata L. var. bonariensis (Lam.) Spreng on dystrophic Red Latosol on metabolite production (total phenols, total flavonoids and hibalactone content). It was used the soil of a rural property in the municipality of Anápolis - Goiás (Brazil). The experimental design was completely
\end{abstract}


randomized, in a controlled environment. The experiment involved the following dosages of fertilization: nitrogen $(0$; $30 ; 45 ; 60$ e $75 \mathrm{~kg}$ of N.ha $\left.{ }^{-1}\right)$; phosphate $\left(0 ; 120 ; 150 ; 180\right.$ e $210 \mathrm{~kg}$ of $\left.\mathrm{P}_{2} \mathrm{O}_{5} \cdot \mathrm{ha}^{-1}\right)$ and potassium $(0 ; 25 ; 50 ; 75$ e 100 $\mathrm{kg}$ of $\left.\mathrm{K}_{2} \mathrm{O} \cdot \mathrm{ha}^{-1}\right)$. The maximum contents of total phenols were with the medium level of nitrogen, zero level of phosphorous and highest level of potassium. For the total flavonoid, the maximum contents were obtained with the medium levels of nitrogen and potassium and zero level of phosphorus. Finally, the hibalactone content was favored by highest level of nitrogen and zero levels of phosphorus and potassium.

Keywords: Chemical and organic fertilization; Total phenols; Total flavonoids; Hibalactone.

\section{Resumo}

O conhecimento das plantas medicinais é de grande importância para a saúde popular. Por outro lado, os níveis de metabólitos secundários em plantas medicinais é um parâmetro importante a ser avaliado. $\mathrm{O}$ estudo da nutrição das plantas e da produção de metabólitos pode proporcionar a identificação de fatores benéficos e também saber se existem efeitos deletérios dessa fertilização / nutrição. Neste estudo, foram realizados três experimentos (fertilização com nitrogênio, fosfato e potássio) na cultura de Hydrocotyle umbellata L. var. bonariensis (Lam.) Spreng no Latossolo Vermelho distrófico na produção de metabólitos (teor de fenóis totais, flavonóides totais e hibalactona). Foi utilizado o solo de uma propriedade rural no município de Anápolis - Goiás (Brasil). O delineamento experimental foi inteiramente casualizado, em ambiente controlado. $\mathrm{O}$ experimento envolveu as seguintes dosagens de fertilização: nitrogênio $\left(0 ; 30 ; 45 ; 60\right.$ e $75 \mathrm{~kg}$ de N.ha $\left.{ }^{-1}\right)$; fosfato $\left(0 ; 120 ; 150 ; 180\right.$ e $210 \mathrm{~kg} \mathrm{de} \mathrm{P}_{2} \mathrm{O}_{5}$.ha $\left.\mathrm{ha}^{-1}\right)$ e potássio $(0 ; 25 ; 50 ; 75$ e $100 \mathrm{~kg}$ de $\mathrm{K}_{2} \mathrm{O} \cdot \mathrm{ha}^{-1}$ ). Os teores máximos de fenóis totais foram com o nível médio de nitrogênio, nível zero de fósforo e nível mais alto de potássio. Para o flavonóide total, os teores máximos foram obtidos com os níveis médios de nitrogênio e potássio e nível zero de fósforo. Por fim, o conteúdo de hibalactona foi favorecido pelo maior nível de nitrogênio e níveis zero de fósforo e potássio.

Palavras-chave: Fertilização química e orgânica; Fenóis totais; Flavonóides totais; Hibalactone.

\section{Resumen}

El conocimiento de las plantas medicinales es de gran importancia para la salud popular. Por otro lado, los niveles de metabolitos secundarios en plantas medicinales es un parámetro importante a evaluar. El estudio de la nutrición de las plantas y la producción de metabolitos puede proporcionar la identificación de factores beneficiosos y también saber si existen efectos nocivos de esta fertilización / nutrición. En este estudio se realizaron tres experimentos (fertilización con nitrógeno, fosfato y potasio) en el cultivo de Hydrocotyle umbellata L. var. bonariensis (Lam.) Spreng en latosol rojo distrófico sobre la producción de metabolitos (contenido de fenoles totales, flavonoides totales e hibalactona). Se utilizó el suelo de una propiedad rural en la ciudad de Anápolis - Goiás (Brasil). El diseño experimental fue completamente al azar, en un ambiente controlado. El experimento involucró las siguientes dosis de fertilización: nitrógeno $\left(0 ; 30 ; 45 ; 60\right.$ y $75 \mathrm{~kg}$ de N.ha $\left.{ }^{-1}\right)$; fosfato $\left(0 ; 120 ; 150 ; 180\right.$ y $210 \mathrm{~kg}$ de $\mathrm{P}_{2} \mathrm{O}_{5}$.ha- $\left.\mathrm{ha}^{-1}\right)$ y potasio $(0 ; 25 ; 50 ; 75 \mathrm{y}$ $100 \mathrm{~kg}$ de $\left.\mathrm{K}_{2} \mathrm{O} \cdot \mathrm{ha}^{-1}\right)$. Los niveles máximos de fenoles totales fueron con el nivel promedio de nitrógeno, el nivel cero de fósforo y el nivel más alto de potasio. Para el flavonoide total, los niveles máximos se obtuvieron con los niveles promedio de nitrógeno y potasio y el nivel cero de fósforo. Finalmente, el contenido de hibalactona se vio favorecido por el mayor nivel de nitrógeno y los niveles cero de fósforo y potasio.

Palabras clave: Fertilización química y orgánica; Fenoles totales; Flavonoides totales; Hibalactona.

\section{Introduction}

The use of plants in the treatment and cure of diseases is as old as the human species. Fertile soils have sustained for years civilizations and the creation of wealth in countless regions of the world (RAIJ, 1991). Modern agriculture may have its origin in the 1930s to the 1960s, with many medicines and lack of study of medicinal plants being relegated to the background, being replaced by industrialized drugs. However, the use of medicinal plants has received attention again of researchers, health professionals, as well as the general population, in order to value the therapeutic resources of popular medicine (SILVA et al. 2012).

It is necessary scientific basis to evaluate the efficacy and possible risks of plants uses, which involves botanical, chemical, pharmacological and toxicological studies, in addition to the development of appropriate pharmaceutical forms and techniques for quality control, in the case of the commercialization of plants as medicines (PASCHOAL, 1994). There is little information on the nutritional aspects of native plants and their development in cultivated environments, and it is necessary to define behavior patterns for the optimization of production and future yields, especially in medicinal areas (MARTINS et al., 1998).

The cultivation of medicinal plants, when poorly conducted, can generate plants with active products in small 
quantities, making their commercialization unfeasible or, in the opposite way, increasing the amount of substances considered toxic, making the product harmful and, therefore, of therapeutic use unfeasible (FREIRE, 2004).

The use of medicinal plants and good quality foods (free of pesticides) represent a need for the health of the population. Thus, medicinal plants are increasingly regaining a larger share in medicine. With the awareness of side effects and contraindications in the use of synthetic drugs, the use of herbal medicines is increasing (PINTO, 2000).

The species Hydrocotyle umbellata L., also known as acariçoba in Brazil, is of great interest in phytotherapy and especially in Ayurvedic medicine. This is due to its anxiolytic, anti-inflammatory, and memory stimulant effects (Santana, 2001). The species is a rustic plant and, in the crops already made, the attack of pests was not verified. The only disease identified so far is rust, caused by the fungus Uromices sp, being its attack observed only in poorly conducted crops and without causing great economic damage.

The chemical elements considered essential for cultivated plants may not be essential for medicinal plants, i.e. it does not represent the desirable importance and their supply may even be undesirable. In this context, there is an increase of the studies regarding the contribution of the nitrogen, phosphate and potassium fertilization on active compounds of medicinal plants.

The nutritional evaluation of the crop of Hydrocotyle umbellata L. is important from the agronomic point of view, because of the therapeutically potential of the species. Thus, this work aimed to evaluate the nitrogen, phosphate and potassium fertilization for adequate and better production of secondary metabolites of the species.

\section{Methodology}

The present work was conducted at the Central Campus, Anápolis (CET) of the State University of Goiás (UEG), with altitude of 1096 meters, with average annual rainfall of $1441 \mathrm{~mm}$, between the geographic coordinates 16"22'57' of south altitude and 48"56'47' of west longitude, located in the municipality of Anápolis - Goiás. The region has a tropical climate and is considered AW by the Köppen and Geiger classification (CLIMA Anápolis, 2020 - https://pt.climate-data.org/). Average temperature of the region is between $18^{\circ} \mathrm{C}$ and $23^{\circ} \mathrm{C}$ (Climatempo, 2019 - https://www.climatempo.com.br/). The predominant soil of the region is the typical dystrophic Red Latosol.

The soil was used from a rural property in the municipality of Anápolis - Goiás, at geographic coordinates 16"15'25' of south altitude and 49"01'43' of west longitude. Three experiments were conducted with the same soil in the same locality, differing the evaluation of the primary macronutrient (nitrogen, phosphate, and potassium fertilization). The experiment started in August 2019, performing soil analysis, fertilization, planting, crop conduction, harvesting, evaluation of dry matter, metabolite contents, and statistical analysis of the data.

The experiment was conducted in a completely randomized design, because it is the most appropriate for the conditions of this study, in pots (Banzato \& Kronka, 1989). The data were submitted to variance analysis, and the results were compared by the Tukey test, at the level of $5 \%$ probability significance, and submitted to regression analysis, thus defining the respective regression equations and response curves.

As the experiment was carried out in plastic gardens of $45 \mathrm{~cm}$ x $15 \mathrm{~cm}$ x $15 \mathrm{~cm}$, these constituted the plots. In each pot, seven samples of $H$. umbellata seedlings were planted, with subsequent choice of five samples per pot, uniformizing it. The cultural treatments were carried out according to the need of the culture. Watering was done manually during the crop cycle. All experiments had five treatments and four replicates each, totaling 20 plots.

Nitrogen fertilization treatments were : I) control; II) $30 \mathrm{~kg}$ of N.ha-1; III) $45 \mathrm{~kg}$ of N.ha-1; IV) $60 \mathrm{~kg}$ of N.ha-1 and V) $75 \mathrm{~kg}$ of N.ha-1, and the amount of phosphorus $\left(150 \mathrm{~kg} \cdot \mathrm{ha}^{-1}\right)$ and potassium $\left(50 \mathrm{~kg} \cdot \mathrm{ha}^{-1}\right)$ was the same for the plots. Its cultivation was carried out until harvest at 97 days after planting the seedlings. 
The experiment to evaluate phosphorus was used at the same amount of nitrogen $\left(50 \mathrm{~kg} . \mathrm{ha}^{-1}\right)$ and potassium $(50 \mathrm{~kg}$. $\mathrm{ha}^{-1}$ ) in the plots and the treatments were: I) control; II) $120 \mathrm{~kg}_{\text {of }} \mathrm{P}_{2} \mathrm{O}_{5} \cdot \mathrm{ha}^{-1}$; III) $150 \mathrm{~kg}_{\text {of }} \mathrm{P}_{2} \mathrm{O}_{5} \cdot \mathrm{ha}^{-1}$; IV) $180 \mathrm{~kg}_{\text {of }} \mathrm{P}_{2} \mathrm{O}_{5} \cdot \mathrm{ha}^{-1}$; V) $210 \mathrm{~kg}$ of $\mathrm{P}_{2} \mathrm{O}_{5} \cdot \mathrm{ha}^{-1}$. Its harvest was at 90 days after planting.

Regarding the potassium experiment, the treatments were: I) control; II) $25 \mathrm{~kg} \mathrm{of}_{2} \mathrm{O}$.ha- ${ }^{-1}$;II) $50 \mathrm{~kg}$ of $\mathrm{K}_{2} \mathrm{O}$.ha-1 ; IV) $75 \mathrm{~kg}$ of $\mathrm{K}_{2} \mathrm{O} \mathrm{ha}^{-1}$; V) $100 \mathrm{~kg}$ of $\mathrm{K}_{2} \mathrm{O} \cdot \mathrm{ha}^{-1}$. The amount of nitrogen $\left(50 \mathrm{~kg}\right.$. ha- $\left.{ }^{-1}\right)$ and phosphorus $\left(150 \mathrm{~kg}^{-\mathrm{ha}^{-1}}\right)$ was the same in all plots. Harvest performed at 93 days after planting.

Due to a rainy season, the plots were placed under canvas protection two days before collection to reduce the volumetric moisture of the gardens as much as possible, favoring the removal of the entire root system. After harvest, the plants were sent to the Federal University of Goiás (Goiás - Brazil) for drying and evaluation of metabolites (total phenols, total flavonoids and hibalactone contents). The data of the metabolites were submitted to analysis of variance, regression analysis, thus defining the respective regression equations and response curves.

\subsection{Obtaining the vegetable drug:}

The plant material from the cultivated plots was removed from the pots, previously described, washed with running water, dried in a greenhouse with forced air circulation at $40^{\circ} \mathrm{C}$ and crushed. The plant drug obtained in the form of powder was packed under light and moisture and under refrigeration at $-18^{\circ} \mathrm{C}$.

\subsection{Determination of total phenol and total flavonoid content}

Total phenolic content (TPc) was determined, in triplicate, according to Mole \& Waterman (1987). For that, $1 \mathrm{~mL}$ of extract was dissolved in $5 \mathrm{~mL}$ of ethanol $70 \%$ in a volumetric flask. Sample's spectrophotometer absorbance was measured at $510 \mathrm{~nm}$. Standard curves were prepared with tannic acid. Total flavonoid content ( $\mathrm{TFc}$ ) was determined, in triplicate, following the method by Rolim et al. (2005). Sample's spectrophotometer absorbance was measured at $361 \mathrm{~nm}$. Standard curves were prepared with rutin.

\subsection{Determination of hibalactone content}

The hibalactone quantifications were performed by High Performance Liquid Chromatography (HPLC) using the chromatographic conditions established by Oliveira et al. (2019). Hibalactone content (Hc) was determined by comparison with the standard (isolated hibalactone) obtained in our previous work (Oliveira et al., 2019). Stock solutions of the standard were prepared in the range of $10-150 \mu \mathrm{g} \mathrm{mL}^{-1}$. The mean of the three calibration curves and the equation resulting from the linear regression were used to determine the Hc. The method was validated following the Brazilian National Health Surveillance Agency guidelines (data not shown) (Brasil, 2017).

\section{Results and Discussion}

At 97 days, the plots of the nitrogen fertilization experiment were collected, moving to the evaluation of secondary metabolites. The secondary metabolites evaluated were the hibalactone content (Table 1), the total phenols content (Table 2) and the total flavonoid content (Table 3). The evaluations were carried out separately in the aerial mass and in the subterraneous mass, and the sum of the two is the whole plant. Means were compared by the Tukey test as a function of nitrogen doses. 
Table 1. Hibalactone content (\%) in the acariçoba crop as a function of saturation correction applied before planting and evaluated at 97 days of cultivation.

\begin{tabular}{|c|c|c|c|c|c|c|}
\hline Dose (kg.ha-1) & Aerial mass & & Subterarnous mass & & Whole & \\
\hline 0 & 0,0280039 & $\mathrm{~d}$ & 0,0150515 & $\mathrm{~d}$ & 0,0430554 & $\mathrm{~d}$ \\
\hline 30 & 0,0353356 & $\mathrm{c}$ & 0,0186887 & $\mathrm{c}$ & 0,0540243 & $\mathrm{c}$ \\
\hline 45 & 0,0416440 & $\mathrm{~b}$ & 0,0204697 & $\mathrm{~b}$ & 0,0621137 & $\mathrm{~b}$ \\
\hline 60 & 0,0352885 & $\mathrm{c}$ & 0,0263069 & $\mathrm{a}$ & 0,0615954 & $\mathrm{~b}$ \\
\hline 75 & 0,0461946 & $\mathrm{a}$ & 0,0200950 & $\mathrm{~b}$ & 0,0662897 & a \\
\hline
\end{tabular}

Where: $\mathrm{a}, \mathrm{b}, \mathrm{c}$ and $\mathrm{d}$ are mean differences by the Tukey test. Source: Authors.

The dose that had the best result for hibalactone content in both the aerial mass and whole total plant was $75 \mathrm{~kg} . \mathrm{ha} \mathrm{a}^{-1}$ and the mean treatment was statistically higher than the other. The treatment of $60 \mathrm{~kg} \cdot \mathrm{ha}^{-1}$ showed the best content when the hibalactone content was evaluated in the subterranous mass.

Nitrogen fertilization has a positive effect on hibalactone content according to the results obtained from the content in the whole plant. The response curve that best adjusted the nitrogen dose data and hibalactone content was the linear equation: $\mathrm{y}$ $=0,0003 \mathrm{x}+0,0445\left(\mathrm{r}^{2}=0,9408\right)$.

Table 2. Total phenols content (\%) in the acariçoba crop as a function of the saturation correction applied before planting and evaluated at 97 days of cultivation.

\begin{tabular}{|c|c|c|c|c|c|c|}
\hline Dose $\left(\mathrm{kg} \cdot \mathrm{ha}^{-1}\right)$ & Aerial mass & & Subterranous mass & & Whole plant & \\
\hline 0 & 2,7232788 & $\mathrm{~b}$ & 0,1533014 & $\mathrm{~d}$ & 2,8765803 & $\mathrm{~b}$ \\
\hline 30 & 2,4730286 & $\mathrm{~d}$ & 0,2867682 & $\mathrm{a}$ & 2,7597968 & $\mathrm{~d}$ \\
\hline 45 & 2,8400623 & $\mathrm{a}$ & 0,1811070 & $\mathrm{c}$ & 3,0211693 & $\mathrm{a}$ \\
\hline 60 & 2,1560449 & e & 0,2293034 & $\mathrm{~b}$ & 2,3853483 & e \\
\hline 75 & 2,6120565 & $\mathrm{c}$ & 0,2367182 & $\mathrm{~b}$ & 2,8487747 & $\mathrm{c}$ \\
\hline
\end{tabular}

Where: a, b, c, d and e are mean differences by the Tukey test. Source: Authors.

The dose of $45 \mathrm{~kg} \cdot \mathrm{ha}^{-1}$ nitrogen was the one that presented the best result for the total phenol content in both the aerial mass and the whole plant, and the average was statistically higher than the other nitrogen doses. The treatment of the best result for the total phenols for the higher production of the metabolite in the subterraneous mass was $30 \mathrm{~kg} \cdot \mathrm{ha}^{-1}$ of nitrogen.

Nitrogen fertilization had a variable effect on the doses of the element, whereas the maximum point of phenol content was the intermediate dose and the response curve that best adjusted the nitrogen dose data and the total phenol content was the fourth degree polynomial equation: $y=0,000002 x^{4}-0,0003 x^{3}+0,0145 x^{2}-0,2245 x+2,8766\left(r^{2}=0,9999\right)$. 
Table 3. Total flavonoid content (\%) in the acariçoba crop as a function of the saturation correction applied before planting and evaluated at 97 days of cultivation.

\begin{tabular}{crrrrrr}
\hline Doses $\left(\mathrm{kg}^{-h a}{ }^{-1}\right)$ & Aerial mass & & Subterraneous mass & Whole plant & \\
\hline 0 & 2,0832258 & $\mathrm{c}$ & 0,1147742 & $\mathrm{~b}$ & 2,1980000 & $\mathrm{~b}$ \\
30 & 2,0058065 & $\mathrm{~d}$ & 0,1218710 & $\mathrm{a}$ & 2,1276774 & $\mathrm{c}$ \\
45 & 2,3735484 & $\mathrm{a}$ & 0,0876774 & $\mathrm{~d}$ & 2,4612258 & $\mathrm{a}$ \\
60 & 2,1090323 & $\mathrm{~b}$ & 0,1102581 & $\mathrm{~b}$ & 2,2192903 & $\mathrm{~b}$ \\
75 & 2,1154839 & $\mathrm{~b}$ & 0,1025161 & $\mathrm{c}$ & 2,2180000 & $\mathrm{~b}$ \\
\hline
\end{tabular}

Where: $a, b, c$ and d are mean differences by the Tukey test. Source: Authors.

As for the total phenol content the dose of $45 \mathrm{~kg} \cdot \mathrm{ha}^{-1}$ nitrogen was the one that favored the best results for the total flavonoid content in both the aerial mass and the total plant, with the average being statistically higher and the treatment of 30 $\mathrm{kg} \cdot \mathrm{ha}^{-1}$ nitrogen was the best result for the total flavonoids as the higher production of the content in the subterraneous mass.

Nitrogen fertilization also presented a variable effect regarding the doses of the element for flavonoid content similar to that of phenols and also had as response curve of best fit to the data the polynomial equation of fourth degree $y=0,0000009 \mathrm{x}^{4}$ $-0,0002 \mathrm{x}^{3}+0,0083 \mathrm{x}^{2}-0,1362 \mathrm{x}+2,198\left(\mathrm{r}^{2}=0,9999\right)$.

Vieira et al. (2011); Serra et al. (2011); Serra et al. (2013); Rodrigues et al. (2014) also evaluated the nitrogen fertilization behavior in medicinal plants and verified the positive effect on plant growth with increased doses.

According to Martins et al. (1998) the increase in nitrogen favors the production of alkaloides in the lobe, while in poppy and bean the increase in nitrogen favors the production of alkaloides. Abreu et al. (2002) observed increased mucilage with increased nitrogen supply. Mapeli et al. (2005) report that nitrogen does not influence the production of essential oil.

Nitrogen fertilization favored the production of metabolites. Regarding hibalactone content, the maximum dosage was the best result, and the intermediate dosage of the others were the best for the production of total phenols and total flavonoids, results close to those described by Martins et al. (1998) for the wolfand Abreu et al. (2002), Mapeli et al. (2005) have a more diverse result yet where there was no influence on the production of essential oil.

The evaluation of phosphate fertilization was performed before the others, and the crop was harvested 90 days after planting. Hibalactone content (Table 4), total phenol content (Table 5) and total flavonoid content (Table 6) were evaluated. The production of secondary metabolites was all in relation to the doses of phosphorus added in the plots.

Table 4. Hibalactone content (\%) in the acariçoba crop as a function of fertilization applied before planting and evaluated at 90 days of cultivation.

\begin{tabular}{crrrrrrr}
\hline Doses $\left(\mathrm{kg}^{\left.-h^{-1}\right)}\right.$ & Aerial mass & Subterraneous mass & & Whole plant \\
\hline 0 & 0,0398264 & $\mathrm{~b}$ & 0,0398870 & $\mathrm{a}$ & 0,0797134 & $\mathrm{a}$ \\
120 & 0,0415890 & $\mathrm{a}$ & 0,0298611 & $\mathrm{c}$ & 0,0714501 & $\mathrm{~b}$ \\
150 & 0,0394689 & $\mathrm{~b}$ & 0,0230238 & $\mathrm{~d}$ & 0,0624927 & $\mathrm{c}$ \\
180 & 0,0398922 & $\mathrm{~b}$ & 0,0305801 & $\mathrm{~b}$ & 0,0704723 & $\mathrm{~b}$ \\
210 & 0,0383030 & $\mathrm{c}$ & 0,0170657 & $\mathrm{e}$ & 0,0553687 & $\mathrm{~d}$ \\
\hline
\end{tabular}

Where: $\mathrm{a}, \mathrm{b}, \mathrm{c}, \mathrm{d}$ and e are mean differences by the Tukey test. Source: Authors.

Table 4 shows hibalactone content for acariçoba crop as a function of phosphorus doses. These means of these treatments differed statistically and the dosage control that it had not added phosphorus both the subterraneous mass and the whole plant was the one of higher values, differing from the other treatments. As for the aerial mass, the treatment that was 
added $120 \mathrm{~kg} \cdot \mathrm{ha}^{-1}$ of phosphorus was statistically superior and different from the other.

The regression equation for phosphorus doses and hibalactone content that generated the production curve in the entire acariçoba plant was a fourth degree polynomial, with the equation: $y=-0,000000001 x^{4}+0,000007 x^{3}-0,0001 x^{2}+0,006 x+$ $0,797\left(r^{2}=0,9999\right)$;

Table 5. Total Phenols content (\%) in the acariçoba crop as a function of fertilization applied before planting and evaluated at 94 days of cultivation.

\begin{tabular}{crrrrrr}
\hline Doses $\left(\mathrm{kg}^{\left.-h \mathrm{~h}^{-1}\right)}\right.$ & Aerial mass & & Subterraneous mass & & Whole plant \\
\hline 0 & 3,8966745 & $\mathrm{a}$ & 0,3590628 & $\mathrm{a}$ & 4,2557372 & $\mathrm{a}$ \\
120 & 3,2349016 & $\mathrm{~b}$ & 0,2719386 & $\mathrm{e}$ & 3,5068402 & $\mathrm{~b}$ \\
150 & 2,8178178 & $\mathrm{c}$ & 0,3034516 & $\mathrm{~d}$ & 3,1212694 & $\mathrm{c}$ \\
180 & 2,6398621 & $\mathrm{~d}$ & 0,3238424 & $\mathrm{c}$ & 2,9637044 & $\mathrm{~d}$ \\
210 & 2,3228784 & $\mathrm{e}$ & 0,3349646 & $\mathrm{~b}$ & 2,6578430 & $\mathrm{e}$ \\
\hline
\end{tabular}

Where: a, b, c, d and e are mean differences by the Tukey test. Source: Authors.

In Table 5, the behavior of the total phenol content as a function of phosphorus doses applied to the soil differed statistically for all treatments in all evaluated parts. The control treatment that no phosphorus was added was the one with the highest value in phenol production. It is observed that the addition of phosphorus decreased the production of total phenols in the whole plant.

The production curve of total phenols as a function of phosphorus treatments in the whole acariçoba plant was the linear equation: $\mathrm{y}=-0,0075 \mathrm{x}+4,296\left(\mathrm{r}^{2}=0,9864\right)$.

According to Table 6, we have the average results of the total flavonoid content for the acariçoba crop. The treatments differed statistically in all results. The treatment without phosphorus addition, that is, the control had the best results for the production of total flavonoids, aerial mass, subterraneous mass and the total plant. Being that by adding phosphorus to the soil, it favored the reduction of the total flavonoid content.

Table 6. Total Flavonoid content (\%) in the acariçoba crop as a function of fertilization applied before planting and evaluated at 94 days of cultivation.

\begin{tabular}{|c|c|c|c|c|c|c|}
\hline Doses $\left(\mathrm{kg} \cdot \mathrm{ha}^{-1}\right)$ & Aerial mass & & Subterraneous mass & & Whole plant & \\
\hline 0 & 2,3864516 & $\mathrm{a}$ & 0,1418710 & $\mathrm{a}$ & 2,5283226 & $\mathrm{a}$ \\
\hline 120 & 2,3348387 & $\mathrm{~b}$ & 0,1083226 & $\mathrm{e}$ & 2,4431613 & $\mathrm{~b}$ \\
\hline 150 & 1,7412903 & $\mathrm{~d}$ & 0,1173548 & $\mathrm{~d}$ & 1,8586452 & $d$ \\
\hline 180 & 1,6767742 & $\mathrm{e}$ & 0,1250968 & $\mathrm{c}$ & 1,8018710 & $\mathrm{e}$ \\
\hline 210 & 1,9477419 & $\mathrm{c}$ & 0,1380000 & $\mathrm{~b}$ & 2,0857419 & $\mathrm{c}$ \\
\hline
\end{tabular}

Where: $a, b, c, d$ and e are mean differences by the Tukey test. Source: Authors.

The production curve that best adjusted the data of the total flavonoid content produced as a function of phosphorus dose was a fourth degree equation: $y=-0,00000002 x^{4}+0,00001 x^{3}-0,0019 x^{2}+0,1098 x+2,5283\left(r^{2}=0,9999\right)$.

When we verified in the literature articles that evaluated the behavior in medicinal plants of phosphate fertilization, authors such as Brondani et al (2008); Benedetti et al. (2009); Gassi et al. (2009); Vieira et al. (2011); Serra et al. (2011); Rodrigues et al. (2014); Heitor et al. (2016) verified the positive effect on plant growth with the increase in phosphorus doses. Amarante et al. (2007) and Amarante et al. (2012) observed that the increase in phosphorous dosage increased the absorption of nutrients by plants.

Authors such as Abreu et al. (2002) observed increased mucilage with increased phosphorus supply. Mapeli et al. (2005) reported that phosphorus did not influence the production of essential oil. Souza et al. (2006) reported that increased phosphorus supply increases hypericin in soil without phasing. As for the total flavonoid contents Costa et al. (2007) concluded 
that phosphorous doses did not influence the total flavonoid content and Vieira et al. (2015) identified the increase in flavonoid content with increased phosphorus dose.

When observing the growth of phosphorus dose in the production of all secondary metabolites evaluated, it is perceived that there was a decrease in their content and the treatment without adding phosphorus was the best result. Comparing with the results of Abreu et al. (2002), Souza et al. (2006) and Vieira et al. (2015), the results are contrary because they observed an increase in metabolites with increased phosphorus dosage. The accounts of Mapeli et al. (2005) and Costa et al. (2007) differ more because it did not influence the contents of essential oil.

Crop evaluation was performed at 93 days after planting, and the variables evaluated secondary metabolites were: hibalactone content (Table 7); total phenol content (Table 8) and total flavonoid content (Table 9). The data were the productivity of the contents evaluated in the aerial mass, subterraneous mass and the sum of the two that is the total plant mass, and the production was as a function of the potassium doses that were added in the acariçoba crop. The data obtained were compared by the Tukey test.

Table 7. Hibalactone content (\%) in the acariçoba crop as a function of the saturation correction applied before planting and evaluated at 93 days of cultivation.

\begin{tabular}{crrrrrrr}
\hline Doses $\left(\mathrm{kg}^{-1} \mathrm{ha}^{-1}\right)$ & Aerial mass & Subterraneous mass & & Whole plant \\
\hline 0 & 0,0489909 & $\mathrm{~b}$ & 0,0366357 & $\mathrm{a}$ & 0,0856266 & $\mathrm{a}$ \\
25 & 0,0621523 & $\mathrm{a}$ & 0,0195960 & $\mathrm{c}$ & 0,0817483 & $\mathrm{~b}$ \\
50 & 0,0379521 & $\mathrm{~d}$ & 0,0244162 & $\mathrm{~b}$ & 0,0623684 & $\mathrm{c}$ \\
75 & 0,0244929 & $\mathrm{e}$ & 0,0140185 & $\mathrm{e}$ & 0,0385114 & $\mathrm{e}$ \\
100 & 0,0406587 & $\mathrm{c}$ & 0,0167297 & $\mathrm{~d}$ & 0,0573884 & $\mathrm{~d}$ \\
\hline
\end{tabular}

Where: a, b, c, d and e are mean differences by the Tukey test. Source: Authors.

For the culture of acariçoba with the potassium element the dose of $0 \mathrm{~kg} \cdot \mathrm{ha}^{-1}$ potassium was higher and statistically different from the other in hibalactone production for the subterraneous mass and the total plant. As for the aerial mass, the dosage of $25 \mathrm{~kg} \cdot \mathrm{ha}^{-1}$ potassium was higher and statistically different from the other potassium doses.

The characteristic curve of hibalactone production as a function of potassium doses is a fourth degree polynomial equation, and the equation is: $y=0,00000004 x^{4}-0,0000005 x^{3}+0,000005 x^{2}-0,00006 x+0,0856\left(r^{2}=0,9999\right)$. This curve demonstrated the effect of decreasing hibalactone production with the increase of potassium dose.

Table 8. Total phenols content $(\%)$ in the acariçoba crop as a function of the saturation correction applied before planting and evaluated at 93 days of cultivation.

\begin{tabular}{crrrrrr}
\hline Doses $\left(\mathrm{kg}^{\left.-h^{-1}\right)}\right.$ & Aerial mass & Subterraneous mass & & Whole plant \\
\hline 0 & 2,5175175 & $\mathrm{c}$ & 0,1996441 & $\mathrm{~b}$ & 2,7171616 & $\mathrm{c}$ \\
25 & 2,5230786 & $\mathrm{c}$ & 0,2052052 & $\mathrm{~b}$ & 2,7282838 & $\mathrm{c}$ \\
50 & 2,5675676 & $\mathrm{~b}$ & 0,2218886 & $\mathrm{a}$ & 2,7894561 & $\mathrm{~b}$ \\
75 & 2,4674675 & $\mathrm{~d}$ & 0,1736922 & $\mathrm{c}$ & 2,6411597 & $\mathrm{~d}$ \\
100 & 2,7010344 & $\mathrm{a}$ & 0,1996441 & $\mathrm{~b}$ & 2,9006785 & $\mathrm{a}$ \\
\hline
\end{tabular}

Where: $a, b, c$ and d are mean differences by the Tukey test. Source: Authors.

The fertilization with the potassium element at a dose of $100 \mathrm{~kg} \cdot \mathrm{ha}^{-1}$ potassium was statistically higher than the other dosages, when we considered the productivity of total phenols in the aerial mass and whole plant. As for the total phenol content in the subterraneous mass, the potassium dosage that was higher was $50 \mathrm{~kg}^{-h^{-1}}$, generating the highest productivity of the total phenols in the subterraneous mass. 
The characteristic curve of the total phenol content in the total acariçoba plant as a function of potassium doses is a fourth degree polynomial equation, this equation being the following: $y=0,000000009 x^{4}-0,00002 x^{3}+0,0009 x^{2}-0,0128 x$ $+2,7172\left(r^{2}=0,9999\right)$.

Table 9. Total flavonoid content (\%) in the acariçoba crop as a function of the saturation correction applied before planting and evaluated at 93 days of cultivation.

\begin{tabular}{crrrrrr}
\hline Doses $\left(\mathrm{kg}^{\left.-h^{-1}\right)}\right.$ & Aerial mass & & Subterraneous mass & & Whole plant \\
\hline 0 & 2,1606452 & $\mathrm{~b}$ & 0,0857419 & $\mathrm{~d}$ & 2,2463871 & $\mathrm{~b}$ \\
25 & 2,0058065 & $\mathrm{c}$ & 0,0999355 & $\mathrm{c}$ & 2,1057419 & $\mathrm{c}$ \\
50 & 2,2058065 & $\mathrm{a}$ & 0,1025161 & $\mathrm{c}$ & 2,3083226 & $\mathrm{a}$ \\
75 & 1,9283871 & $\mathrm{~d}$ & 0,1057419 & $\mathrm{~b}$ & 2,0341290 & $\mathrm{~d}$ \\
100 & 2,0316129 & $\mathrm{c}$ & 0,1089677 & $\mathrm{a}$ & 2,1405806 & $\mathrm{c}$ \\
\hline
\end{tabular}

Where: $a, b, c$ and d are mean differences by the Tukey test. Source: Authors.

The results obtained in the dosage of $50 \mathrm{~kg} \cdot \mathrm{ha}^{-1}$ of potassium added in the aerial mass and in the whole plant generated the highest values so this dosage is statistically superior to the other for the production of the total flavonoid content. When the best dosage for the production of total flavonoids in the subterraneous mass was evaluated, it was verified that the dosage of $100 \mathrm{~kg} \cdot \mathrm{ha}^{-1}$ of potassium was the one that generated the best result and statistically superior to the others.

The production curve of the total flavonoid content in the acariçoba crop as a function of the potassium doses that best adjusted is a fourth-degree polynomial equation, and the equation is adjusted: $y=0,0000002 x^{4}-0,00004 x^{3}+0,0022 x^{2}-$ $0,0402 \mathrm{x}+2,2464\left(\mathrm{r}^{2}=0,9999\right)$.

Following the literature of articles on potassium fertilization of medicinal plants we have some authors such as Veloso et al. (2000); Bull et al. (2001); Almeida et al. (2006) in which all observed that the increase in potassium dosage in the soil increases the productivity of medicinal plants and in a contrary way we have Borges et al. (2002); Dolinski et al. (2007) who found that the increase in potassium generated lower production of medicinal plants.

Costa et al. (2007) reported that potassium did not influence the production of essential oil, different from the results observed in this study in which for potassium influenced the production of hibalactone at the minimum dose, at the intermediate dose for the total flavonoid contents and the best result for the total phenols contents.

\section{Conclusions}

The use of different doses of nitrogen provided different production of metabolites in the acariçoba crop, with the following best results:

- At the dosage of $75 \mathrm{~kg} \cdot \mathrm{ha}^{-1}$ of nitrogen provided the highest hibalactone content in the whole plant;

- The dosage of $45 \mathrm{~kg} \cdot \mathrm{ha}^{-1}$ nitrogen was the one that generated the highest levels of total phenols and total flavonoids in the whole plant;

- The response curves that best adjusted the data were: linear for the hibalactone and polynomial content of fourth degree for the total phenols and total flavonoid contents.

- The phosphate fertilization used resulted in statistical differences in the production of metabolites:

- Phosphorus at the dosage of $0 \mathrm{~kg} \cdot \mathrm{ha}^{-1}$ provided the best result in hibalactone, total phenols and total flavonoids contents for the whole plant;

- The response curves that best adjusted the data were: fourth degree polynomial for the total flavonoid and hibalactone contents, and linear for the total phenol content.

The daily doses of potassium generated different results in the production of metabolites: 
- The dosage of $0 \mathrm{~kg} \cdot \mathrm{ha}^{-1}$ potassium produced the highest hibalactone content; the dosage of $100 \mathrm{~kg} \cdot \mathrm{ha}^{-1}$ potassium produced the highest total phenol content and the dosage of $50 \mathrm{~kg} \cdot \mathrm{ha}^{-1}$ potassium generated the highest total flavonoid content;

- The response curves that best adjusted the data were: fourth degree polynomial for hibalactone, total phenols and total flavonoids.

With this work of nitrogen, phosphate and potassium fertilization in dystrophic soil, with the cultivation of acariçoba, it is certain that the research is far from complete. There is a continuous need to evaluate and seek knowledge of the effects of nutrition and agronomic cultural management of medicinal plants, co-validating with the results of secondary metabolite contents.

\section{References}

Abreu, I. N., Pinto, J. E. B. P., Furtini Neto, A. E., Bertolucci, S. K. V., Ladeira, A. \& Geromel, C. (2002) Nitrogênio e fósforo na produção vegetal e na indução de mucilagem em plantas de insulina. Horticultura Brasileira, 20 (4), 536-40.

Almeida, E. V., Natale, W., Prado, R. M. \& Barbosa, J. C. (2006) Adubação nitrogenada e potássica no desenvolvimento de mudas de maracujazeiro. Ciência Rural. 36 (4), 1138-42.

Amarante, C. V. T., Ernani, P. R. \& Souza, A. G. (2007) Influência da calagem e da adubação fosfatada no acúmulo de nutrientes e crescimento da erva-deSão-João. Horticultura Brasileira, Brasília. 25 (4), 533-7.

Amarante, C. V. T., Ernani, P. R., Souza, A. G. \& Steffens, C. A. (2012) Calagem e adubação fosfatada favorecem o crescimento do capim-limão, Cymbopogon citratus (DC) Stapf. Revista Brasileira de Plantas Medicinais, 14 (1), 92-6.

Banzato, D. A. \& Kronka, S. N. (1989). Experimentação agrícola. FUNEP.

Benedetti, E. L., Serrat, B. M., Santin, D., Brondani, G. E., Reissmann, C. B. \& Biasi, L. A. (2009) Calagem e adubação no crescimento de espinheira-santa [Maytenus ilicifolia (Schrad.) Planch.] em casa de vegetação. Revista Brasileira de Plantas Medicinais, 11 (3), $269-76$.

Borges, A. L., Caldas, R. C., Lima, A. A. \& Almeida, I. E. (2002) Efeito de doses de NPK sobre os teores de nutrientes nas folhas e no solo, e na produtividade do maracujazeiro amarelo. Revista Brasileira de Fruticultura, 24 (1), 208-13.

BRASIL. (2017) Ministério da Saúde. Agência Nacional de Vigilância Sanitária. Resolução RDC n 166 , de 24 de julho de 2017 - Guia para validação de métodos analíticos. Brasília.

Brondani, G. E., Silva, A. J. C., Araujo, M. A., Grossi, F., Wendling, I. \& Carpanezzi, A. A. (2008) Adubação fosfatada no crescimento de mudas de Bauhinia forficata L. Acta Scientiarum Agronomy, 30 (sup), 665-71.

Bull, L. T., Villas Boas, R. L., Fernandes, D. M. \& Bertani, R. M. A. (2001) Fertilização potássica na cultura do alho vernalizado. Scientia Agrícola, Piracicaba. 58 (1), 157-63.

CLIMA Anápolis: Climopgrama, Anápolis. (2021). https://pt.climate-data.org/america-do-sul/brasil/goias/anapolis3192/\#: :text=A n\%C3\%A1polis\%20Clima $\% 20$ (Brasil)\&text $=$ No $\% 20$ inverno $\% 20$ existe $\% 20$ muito $\% 20$ menos, $\%$ C $3 \%$ A 9 dia $\% 20$ anual $\% 20 \mathrm{de} \% 201586 \% 20 \mathrm{~mm}$,

CLIMATEMPO Anápolis: Climatologia. (2019). https://www.climatempo.com.br/climatologia/85/anapolis-go,

Costa, C. A., Alves, D. S., Fernandes, L. A., Martins, E. R., Souza, I. G. B., Sampaio, R. A. \& Lopes, P. S. N. (2007) Nutrição mineral da fava d'anta. Horticultura Brasileira, 25 (1), 24-8.

Dolinski, M. A., Motta, A. C. V., Serrat, B. M., Mio, L. L. M. \& Monteiro, L. B. (2007) Adubação nitrogenada e potássica na produtividade da ameixeira 'reubennel', na região de Araucária - PR. Revista Brasileira de Fruticultura. 29 (2), 364-70.

Freire, M. F. I. (2004). Plantas medicinais: a importância do saber cultivar (5a ed.). Revista científica eletrônica agronomia.

Gassi, R. P., Zárate, N. A. H., Vieira, M. C., Scalon, S. P. Q. \& Mattos, J. K. A. (2009) Doses de fósforo e de cama-de-frango na produção de bardana. Ciência e Agrotecnologia, 33 (3), 692-7.

Heitor, L. C., Freitas, M. S. M., Brito, V. N., Carvalho, A. J. C. \& Martins, M. A. (2016) Crescimento e produção de capítulos florais de calêndula em resposta à inoculação micorrízica e fósforo. Horticultura Brasileira, 34 (1), 26-30.

Mapeli, N. C., Vieira, M. C., Heredia Z. N. A. \& Siqueira, J. M. (2005) Produção de biomassa e de óleo essencial dos capítulos florais da camomila em função de nitrogênio e fósforo. Horticultura Brasileira, 23 (1), 32-7.

Martins, E. R., Castro, D. M., Castellani, D. C. \& Dias, J. E. (1998). Plantas medicinais (2a ed.). UFV.

Mole, S. \& Waterman, P. G. (1987) A critical analysis of techniques for measuring tannins in ecological studies I: techniques for chemically defining tannins. Oecologia. $72(1), 137-47$.

Oliveira, M. G., Almeida, P. H. G., Oliveira, T. L. S., Silva, L. S., Carvalho, F. S., Alves, S. F., Borges, L. L., Santos, P. A., Silva, V. B. \& Paula, J. R. (2019) 
HPLC-PDA method validated for the determination of hibalactone in Hydrocotyle umbellata L. (Araliaceae) subterraneous parts and its ultrasound-assisted extraction optimization. Revista Brasileira de Farmacognosia, Curitiba. 29 (2), 162-70.

Paschoal, A. D. (1994). Produção orgânica de alimentos: agricultura sustentável para os séculos XX e XXI. ESALQ

Pinto, J. E. P. (2000). Cultivo de Plantas Medicinais, Aromáticas e Condimentares. In M. R. Furlan (Org.). Plantas Medicinais: Manejo, Uso e Manipulação. UFLA/FAEPE.

Raij, B. V. (1991). Fertilidade do solo e adubação. Ceres/Potafós.

Rodrigues, D. S., Camargo, M. S., Nomura, E. B., Garcia, V. A., Correa, J. N. \& Vidal, T. C. M. (2014) Influência da adubação com nitrogênio e fósforo na produção de Jambu, Acmella oleracea (L) R. K. Jansen. Revista Brasileira de Plantas Medicinais, 16 (1), 71-6.

Rolim, A., Maciel, C. P. M., Kaneko, T. M., Consiglieri, V. O., Salgado-Santos, I. M. N. \& Velasco, M. V. R. (2005) Validation Assay for Total Flavonoids, as Rutin Equivalents, from Trichilia catigua Adr. Juss (Meliaceae) and Ptychopetalum olachoides Bentham (Olacaceae) commercial extracts. Journal of AOC International 88 (4), 1015-9.

Santana, S. A. (2001) Estudo Farmacognóstico da Acariçoba, Hydrocotyle umbellata L. Apiaceae. Dissertação de mestrado, Universidade Federal de Goiás, Goiânia, GO, Brasil.

Serra, A. P., Marchetti, M. E., Vieira, M. C., Robaina, A. D., Veronesi, C. O., Nascimento, J. M., Matos, F., Conrad, V. A., Morais, H. S. \& Guimarães, F. C. N. (2013) Eficiência nutricional do Nitrogênio e produção de biomassa em Calendula offcinalis L. (Asteraceae) em condições de casa de vegetação. Revista Brasileira de Plantas Medicinais, 15 (1), 78-85.

Serra, A. P., Marchetti, M. E., Vieira, M. C., Silva, M. A. G., Rosa Junior, E. J., Nascimento, J. M. \& Guedes, E. M. S. (2011) Produção de biomassa e absorção de N e P pela Pfaffia glomerata (Spreng.) Pedersen em função de doses de N e P em condições de casa de vegetação. Revista Brasileira de Plantas Medicinais, 13 (3), 265-70.

Silva, W. A., Fagundes, N. C. A., Coutinho, C. A., Soarez, A. C. M., Campos, P. V. \& Figueiredo, L. S. (2012) Levantamento etnobotânico de plantas medicinais na cidade de São João da Ponte - MG. Biofar Revista de Biologia e Farmácia, 7 (1), 122-31.

Souza, A. G., Amarante, C. V. T., Deschamps, F. C. \& Ernani, P. R. (2006) Calagem e adubação fosfatada promovem crescimento inicial e produção de hipericina em erva-de-São-João. Horticultura Brasileira, 24 (4), 421-5.

Veloso, C. A. C., Carvalho, E. J. M., Malavolta, E. \& Muraoka, T. (2000) Resposta de cultivares de pimenta do reino aos nutrientes NPK em um Latossolo Amarelo da Amazônia Oriental. Scientia Agrícola. 57 (2), 343-7.

Vieira, M. C., Perez, V. B., Heredia, Zárate N. A., Santos, M. C., Pelloso, I. A. O. \& Pessoa, S. M. (2011) Nitrogênio e fósforo no desenvolvimento inicial da guavira [Campomanesia adamantium (Cambess.) O. Berg] cultivada em vasos. Revista Brasileira de Plantas Medicinais, 13 (esp), $542-9$.

Vieira, M. C., Ramos, M. B. M., Heredia Zárate, N. A., Luciano, A. T., Gonçalves, W. V., Rodrigues, W. B., Tabaldi, L. A., Carvalho, T. M., Soares, L. F. \& Siqueira, J. M. (2015) Adubação fosfatada associada à cama de frango e sua influência na produtividade e no teor de flavonóides da Marcela (Achyrocline satureioides (Lam.) DC.) em duas épocas de colheita. Revista Brasileira de Plantas Medicinais, 17 (2), $246-53$. 